$$
\begin{aligned}
& \text { قســـم: الصحة ومر اقبــة الأغذيـة. }
\end{aligned}
$$

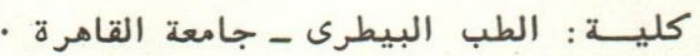

$$
\begin{aligned}
& \text { رئيس القسم : ' أ.د./ عبد الومابطري مرسي فهمي }
\end{aligned}
$$

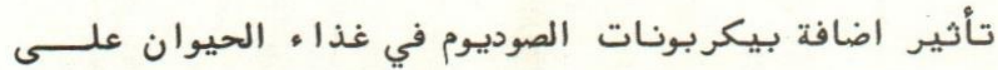

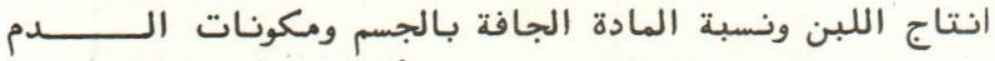

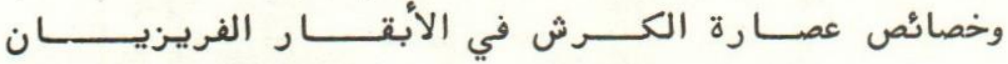

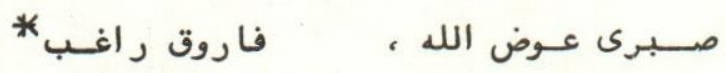

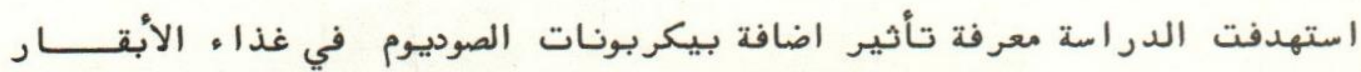

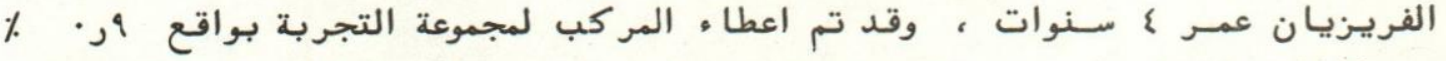

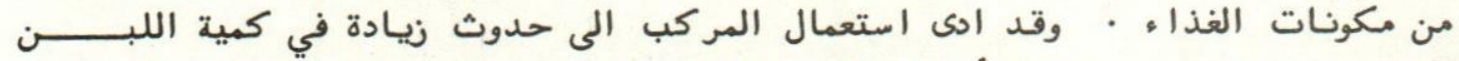

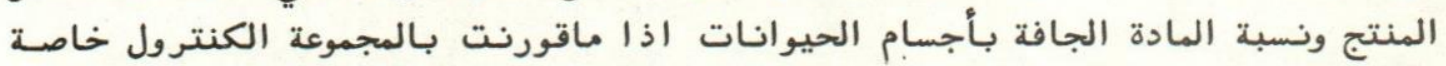

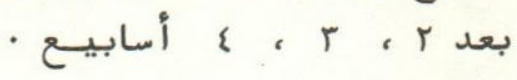

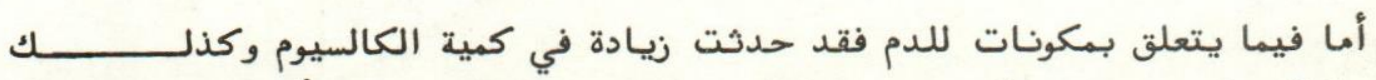

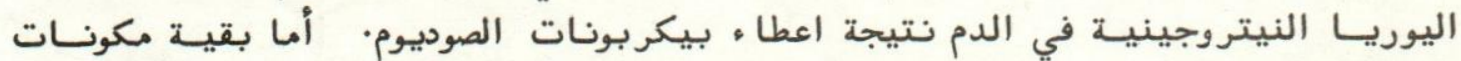

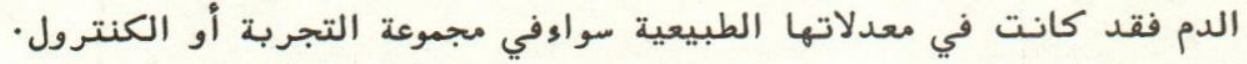

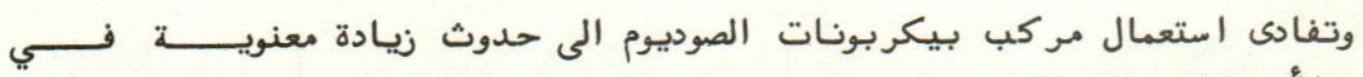

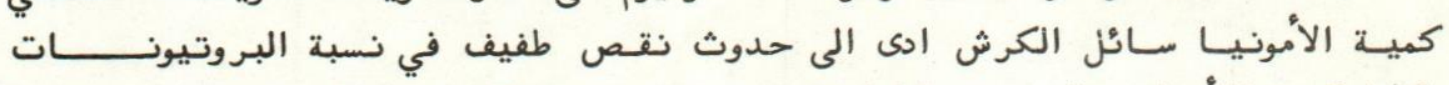

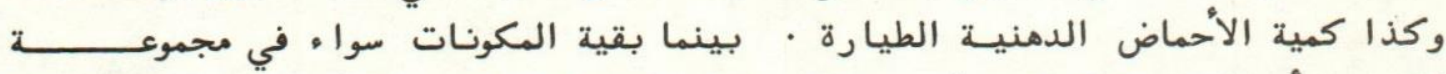

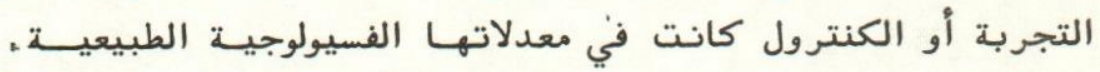

* : ق قسم طب الحيوان - كلية الطب البيطرى ـ جامعة أسيوط. 

Dept. of Hygiene and Food Control, Fac. of Vet. Med., Cairo University, Head of Dept. Prof. Dr. A. Moursy.

\title{
EFFECT OF FEEDING SODIUM BICARBONATE ON MILK PRODUCTION, BLOOD COMPONENTS AND RUMINAL JUICE IN FREISIAN COWS \\ (With 3 Tables)
}

\author{
By \\ S.A. AWADALLA and M.F. RAGHIB* \\ (Received at 9/8/1986)
}

SUMMARY

In El-Abd dairy farm- Sherbeen Dakhahlia governorate 12 dairy Freisian cows 4 years old were signed randomly into two groups as control group and experimental one. The experimental group was given in addition to the control ration sodium biocarbonate $0.8 \%$. The milk yield revealed slight increase in the cows given $\mathrm{NaHCO}_{3}$ with significant increase in the percent of dry matter intake after 2 nd, 3 rd \& 4 th weeks post partum.

Blood analysis showed an increase in blood urea nitrogen and in blood serum calcium as a result of giving $\mathrm{NaHCO}_{3}$ in the ration while the rest of blood parameters were within the normal physiological limits in both control and experimental group.

Examination of the ruminal juice manifested an increase ammonia concentration in the experimental group given $\mathrm{NaHCO}_{3}$. On the contrary propionate and total volatile fatty acids were decreased. The rest of the ruminal juice parameters were within the normal physiological limits in both experimental and control group.

\section{INTRODUCTION}

Effect of feeding certain additives such as sodium bicarbonate on rumen fermentation pattern and on milk production have been examineú extensively but their effects on early lactation have been neglected (EMERY, 1975). In addition the study of the effect of sodium biocarbonate on ruminal juice changes and blood composition is not sufficiently studied. On the other hand sodium biocarbonate is used to adapt cow to increased energy ration especially when the cows are switched at parturition to a high energy ration (THOMAS and EMERY, 1969).

Our aim was to test the effect of sodium biocarbonate additions to cows fed increased energy level, on the milk production, blood composition and changes in the ruminal juice.

Rumen $\mathrm{pH}$. is subjected to certain fluctuation during the course of digestion of a given ration depending on the activity of ruminal flora and the effect of fermentation occurring

* : Dept. of Animal Medicine, Faculty of Vet. Med., Assiut University.

Assiut Vet. Med. J. Vol. 17, No. 34, 1986. 
in the rumen (EL-SEBAI, 1974 and ABD-ELSALAM, 1981). The balance achieved between production and absorption of volatile fatty acids and the buffering power of the rumen is reported to influence principally the $\mathrm{pH}$ of the rumin (PHILLIPSON; 1952). ANNISON and LEWIS (1959) and DAYKINIS (1969) stated that the regulation of the $\mathrm{pH}$ in the rumen mainly takes place by the addition of alkali to the rumen ingesta through the flow of saliva.

\section{MATERIAL and METHODS}

In EL-ABD dairy farm - Sherbeen, Dakhahlia governorate 12 dairy Freisian cows -4 years old of average body weight $400 \mathrm{~kg}$ were paired according to the expected date of calving and subsequent lactation. Each pair were assigned randomly to one of the two treatment groups that were designed, control and experimental. All cows were fed in the dry period ration 15\% of maintainence requirements of the NRC 1978. The animals were fed on hay left free behind them and a concentrate mixture composed mainly of corn added to adjust the ration in order to meet the NRC requirements (1978).

After calving the control and experimental group were switched to a ration containing hay and concentrate mixture ( $400 \mathrm{gm}$ per kilogram milk production). Total dry matter intake was adjusted for $2.5 \%$ of body weight.

The cows of experimental group received sodium biocarbonate at the rate of $0.8 \%$. Rations were adjusted weekly according to NRC 1978 on the bases of milk production plus $10 \%$ allowance.

Milk production was recorded daily while the animal body weight was recorded weekly. Blood samples were analysed one week before calving, and two weeks after calving for serum protein by Mac-FATE (1972), urea nitrogen by GRADENER (1961), blood glucose by OSER (1965), serum calcium by BERSCHNIDER (1971) serum inorganic phosphorous by RAABE (1951) and serum magnesium by OSER (1965).

Rumenal juice were obtained by stomach tube at 1 st and 2 nd week after parturition for determination of $\mathrm{pH}$ of strained rumen fluid by the use of glass electrode $\mathrm{pH}$ meter model Multiscope, Ammonia by CON-WAY (1947); Valatile fatty acids by MARKHAM (1942), while acetate, propionate and butyrates were determined after KORELENKO (1963).

\section{RESULTS}

The percentage of ration dry matter intake and milk production tabulated in table (1) showed no significancy between the levels of food intake after the 2nd, 3rd and 4th weeks post partum in the experimental group when compared with the control one. Also no clear differences in the daily milk yield among experimental and control groups were noted. At the fourth week there was a slight increase found in the experimental group given the sodium bicarbonate.

Blood analysis relating to both control and experimental group is in table (2). There were no significant differences between the two groups and data were within the normal they were significantly increased in experimental group at the first and at the 14th day post partum.

Examination of ruminal juice is shown in table (3). There was no significant changes in $\mathrm{pH}$ values among both experimental and control groups either after seven days or after fourteen days from parturition, while in ammonia showed significant increase as a result of

Assiut Vet. Med. J. Vol. 17, No. 34, 1986. 
EFFECT OF FEEDING SODIUM BICARBONATE

Table (1)

Dry matter intake and milk production in the friesian cows

of the two experimental groups

\begin{tabular}{|c|c|c|}
\hline & \multicolumn{2}{|c|}{ Groups } \\
\hline & Control & Experiment \\
\hline \multicolumn{3}{|c|}{ 1- Dry matter intake (\% of body weight): } \\
\hline 1st week pot partum & 1.90 & 2.00 \\
\hline 2nd week post partum & 2.10 & 2.27 \\
\hline 3rd week post partum & 2.20 & 2.35 \\
\hline 4th week pot partum & 2.35 & 2.45 \\
\hline \multicolumn{3}{|l|}{ 2- Milk yield ( $\mathrm{kg} /$ day): } \\
\hline 1st week post partum & 12 & 13 \\
\hline 2nd week post partum & 15 & 15 \\
\hline 3rd week post partum & 16 & 18 \\
\hline 4th week post partum & 18 & 21 \\
\hline
\end{tabular}

* P significant at 0.05 .

Table (2)

Changes in blood constituents of Freisian cows

\begin{tabular}{|c|c|c|c|c|}
\hline \multirow{2}{*}{ Measurements } & \multicolumn{2}{|c|}{7 days post partum } & \multicolumn{2}{|c|}{14 days post partum } \\
\hline & Control & Experimental & Control & Experimental \\
\hline Serum protein $(\mathrm{gm} / 100 \mathrm{ml}$ serum) & 6.8 & 7.2 & 7.6 & 7.40 \\
\hline Serum alb. & 4.1 & 4.1 & 4.2 & 3.80 \\
\hline Serum glob. & 3.3 & 3.1 & 3.2 & 3.6 \\
\hline Blood urea nitrogen $\mathrm{mg} / 100 \mathrm{ml}$ & 12.6 & $15.00 *$ & 14.10 & $16.00 *$ \\
\hline Blood sugar $\mathrm{mg} / 100 \mathrm{ml}$ & 41.2 & 42.1 & 40.2 & 40.32 \\
\hline Serum Ca $(\mathrm{mg} / 100 \mathrm{ml}$ blood $)$ & 8.65 & $9.13 *$ & 9.01 & $9.87 *$ \\
\hline Serum P.(mg/100 ml blood) & 5.13 & 5.55 & 5.50 & 5.72 \\
\hline Serum $\mathrm{mg}(\mathrm{mg} / 100 \mathrm{ml}$ blood $)$ & 2.14 & 2.04 & 2.34 & 2.10 \\
\hline
\end{tabular}

* P significant at 0.05

Assiut Vet. Med. J. Vol. 17, No. 34, 1986. 


\section{AWADALLA and RAGHIB}

Table (3)

Levels of $\mathrm{pH}$, ammnia, acetate, propionate butyrate and total volatile fatty acids (VAF) in cows ruminal juice.

\begin{tabular}{|c|c|c|c|c|}
\hline \multirow{2}{*}{ Parameters } & \multicolumn{2}{|c|}{7 days post partum } & \multicolumn{2}{|c|}{14 days pot partum } \\
\hline & Control & Experimental & Control & Experimental \\
\hline $\mathrm{PH}$ & 6.1 & 6.7 & 6.3 & 6.9 \\
\hline Ammonia $(\mathrm{mg} / 100 \mathrm{ml})$ & 8.4 & $12.0 *$ & 8.9 & $12.5^{*}$ \\
\hline Acetate & 44.1 & 50.1 & 50.2 & 50.5 \\
\hline Propionate & 31.9 & $28.7 *$ & 31.2 & $28.3 *$ \\
\hline Butyrate & 15.4 & 12.8 & 14.6 & 12.9 \\
\hline Total V.F.A. $(\mathrm{mm} / \mathrm{L})$ & 122.6 & $116.1^{*}$ & 126.1 & $120.2^{*}$ \\
\hline
\end{tabular}

addition of sodium bicarbonate where the level reached $12 \mathrm{mg} / 100 \mathrm{ml}$ ruminal juice after seven days and up to $30 \mathrm{mg} / 100 \mathrm{ml}$ at 14 days post partum. As far as volatile fatty acids were concerned, it was evident that they were significantly decreased 7 days and 14 days post partum, while fatty acids salts (acetate, propionate and butyrate) manifested sinificant decrease in both propionate and butyrate while acetate did not exhibit any sinificant changes as a result of addition of sodium bicarbonate.

\section{DISCUSSION}

Supplementation of the experimental group with sodium bicarbonate $\left(\mathrm{NaHCO}_{3}\right)$ resulted in an incrase in the percent of dry matter. This may be attributed to the improovement effect of $\mathrm{NaHCO}_{3}$ in the process of digestion and consequenitly absorption of essential nutrients necessary for performance of the essential nutrients in the body (LANZAC-PEREZ et al., 1978 and HADJIPAMAJITOU, 1982). This action was also clearly manifested in increasing the milk yield mainly and the third and fourth week post partum. This showed the beneficial effect of adding $\mathrm{NaHCO}_{3}$, to the ration. These results agreed with EMERY et al. (1964), MILLER et al. (1965), HADJIPAMAJITOU (1978) and ERDMAN et al. (1980). In addition it seems reasonable that addition of $\mathrm{NaHCO}_{3}$ to the diet is likely to improve the productivity of cows in early lactation period.

With regards to the effect of $\mathrm{NaHCO}_{3}$ supplementation on the blood constituents, it was clearly evident that it resulted in an increase in blood urea nitrogen 7 days and 14 days from calving. This may be attributed to the fact that addition of $\mathrm{NaHCO}_{3}$ as an alkali promoted the activity of microflora by buffering excess acidity keeping an optimal level of $\mathrm{pH}$ necessry for the activity of microflora (DAYKINI, 1969). In addition calcium level was also increased at the same periods in the experimental group but this increase was within the normal physiological limits. The examination for the rest of blood constituents revealed no significant variation especially, blood protein and its fractions. Also the free fatty acids did not manifest any variation between both experimental and control groups. These results emphasized that addition of $\mathrm{NaHCO}_{3}$ has no deletorious effect and favoured. The normal process of digestion and absorption. These findings agreed with ANINISON and LEWIS (1959) MILLER et al. (1964) and DAYKIN

Assiut Vet. Med. J. Vol. 17, No. 34, 1986. 


\section{EFFECT OF FEEDING SODIUM BICARBONATE}

(1969). The studies of ruminal juice declared that there were no marked variation in the $\mathrm{pH}$ values as a result of addition of $\mathrm{NaHCO}_{3}$. This revealed that the given amount of $\mathrm{NaHCO}_{3}$ is quickly buffered by the ruminal juice and furthermore it 'might act as a stimulating article rather than alkaline one and it neutralized any excess acidity which might be found and consequently the level of $\mathrm{pH}$ is not altered (STANILEY et al. (1972).

On the other hand the changes in the amounts of total volatile fatty acids at 7 days and 14 days post partum pointed to a slight decrease but this was within the normal physiological levels. In addition the significant decrease in the propionate level at the same periods as a result of given $\mathrm{NaHCO}_{3}$ was also within the normal physiological level. These findings go hands by hands with those obtained by SLANINA (1969) and SINGH et al. (1972).

It is evident from the present work that the addition of $\mathrm{NaHCO}_{3}$ by the given dose to the ration of dairy Freisian cows had a favourable effect in promoting the ruminal activity and favoured at the same time the productivity of animal. It seemed also that the use of $\mathrm{NaHCO}_{3}$ was necessary in such diets fed to cows to overcome any excess acidity which may interfer with the optimal activity of rumen and consequently the process of digestion and absorption and finally keeps the health of the animal in a good status.

Assiut Vet. Med. J. Vol. 17, No. 34, 1986. 


\section{AWADALLA and RAGHIB}

\section{REFERENCES}

Abdel Salam, M.N. (1981): Ruminal fluid picture in sheep fed on field stubbles. B.V.Sc. Thesis, Faculty of Vet. Med. Assiut University.

Almond, M.D.; G. Harison and P. Rowinson (1979): The effect of the dietary inclusion of either saliva salt or sodium bicarbonate upon milk yield and composition in dairy cows. Winter Meeting Proc. Brit. Soc. Anim. Prod. Paper 4.

Annison, A. and Lewis, L. (1959): Metabolism in the rumen. Yodon Methuen and Co. Ltd. 11st Ed.

Berischnider, B. (1971): Zurernacarunges physiologicely bedeuping, der selebsbein. Flaschschvein em hinblickayt bas Bewegus gestoungssifdrowm. Diss. Biouss. Fak. Humboldt. Univ. Zur., Berlin.

Con Way, E.J. (1947): Microdiffusion analysis and volumetric errores 2nd Ed. Londnon CrosbyLock Wood and Son. Ltd.

Daykinis, B.P. (1969): Veterinary applied pharmacology therapeutic. Baillier, tendal and Cox. 1st Ed.

Diven, R.H., (1975): Bicarbonates in ruminant nutrition and physiology. Feedstuffs Hugust 4:21.

El-Sebai, A. (1974): Some studies on indigestion in sheep. M.V.Sc. Thesis, Faculty of Vet. Med. Assiut University.

Emery, R.S. (1975): Energy feed for milk production P. 149-156. In Buffers in Ruminant Physiology and Metabolism. M.S. Weinberg and A.L. Sheffiner, Ed. Church. S. Dwight Gompany Inc., N.J.

Emery, R.S.; L.D. Brown and J.W. Thomas (1964): Effect of sodium and calcium carbonates on milk production and composition of milk, blood and rumen contents of cows fed grain ad libitum with restricted roughages. J. Dairy Sci. 47: 1325.

Erdman, R.A., R.L. Botts, R.W. Henken and L.S. Bull. (1980): Effect of dietary sodium bicarbonate and magnesium oxide on production and physiology in early lactation. J. Dairy Sci. 36: 923.

Gradener, E. (1961): Das Praxislaboratorium. 2nd Ed., Georg Thoma Verlag. stuttgard. P. 25. Hadjipamajitou, M. (1982): Effect of sodium biocarbonate in the roughages on milk yield and milk composition of goats, and on rumen fermentation of sheep. J. Dairy Sci., 65: 59-64.

Korelenko, K.A. (1963): Veterinary Laboratory Research. Agriculture Journal Moscow USSR, 3, 119.

Lanaac-Petez, J.; D.G. Harrison, M. Hadjipamajotou and D.G. Armstrong (1978): The effect of the addition of an artificial saliva $t n$ high energy diet fed to early weaned lambs. Paper A., 1-65 in the third world. Congress. Animal Feeding, Madrid, Spain.

MacFate, R.(1972): Introduction to the clinical laboratory chemistry. New York Book Medical Publishers Inc. Chicago U.S.A.

Markham, R. (1942): Steam distillation apparatus suitable for micro-kjeldahi. Amusos. Bopcjeu. K.; 36. 790.

Miller, R.W.; D.R. Waldo, L.A. Noose and R.W. Hemken (1964): Feeding of buffers to dairy cows on a high concentrate ration. J. Animal Sci. 23: 885.

Miller, R.W.; R.W. Hemken, D.R. Waldo, M. Dkarnoto and L.A.. Moore, (1965): Effect of feeding buffers to dairy cows fed a high concentrate low roughage ration. J. Dairy Sci. 48: 1455.

Oser, B.L. (1965): Hawk's physiological chemistry, McGraw Hill Book Compay New York, Toronto, Sydney and London. 
Roabe, S. (1951): Arch, F. Clin. chim. 282, Medizinische, 288 (Cited in Klichling and Freiburg, 1951).

Singh, R.D.N.; B.B. Mahapatro and A.K. Pal (1972): Volatile fatty acids production in the rumen of sheep fed on certain Indian feeds. Indian Vet. J., 49, 984-994.

Slanina, L. (1969): Betrag Zur pathogenese der alkalosen and azidosen der Wielderkauer. Deutsche Tieranstlich Wochenschrift, 67: 628-632.

Staniley, R.W.; N. Kanjanipibil, K. Morita andS.M. Ishizaki (1972): Effect of feeding buffered concentrate rations on the performance and metabolism of lactating dairy cattle in subtropical environment. J. Dairy Sci 55, 959-963.

Thomas, J.W. and R.S. Emery (1969): Addition nature of sodium bicarbonate and magnesium oxide on milk and its fat concentration of milking cows fed restricted-roughage ration. I. Dairy Sci., 52, 1762. 


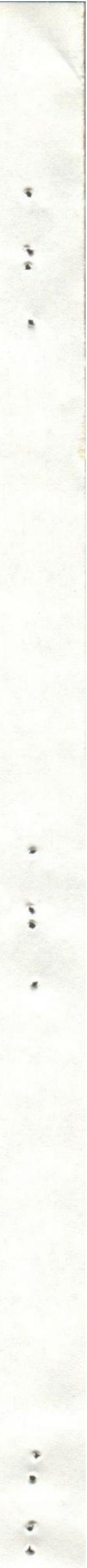

